\title{
Valuation of Phytotoxic Activity of Naturally Occurring Phenolic Compounds*
}

\author{
Yuka Kobayashi** and Misako Ito**
}

\begin{abstract}
Relative phytotoxic activity of 21 phenolic compounds previously reported as allelochemicals was evaluated with aqueous solution test and soil incorporation test. At $1.0 \mathrm{mM}$, aqueous solutions of juglone, coumarin, $t$-cinnamic acid, $o$-hydroxyphenylacetic acid and 3-phenylpropionic acid were most inhibitory to the radicle elongation of lettuce (Lactuca sativa) and Japanese barnyard millet (Echinochloa utilis), followed by salicylic acid, $\beta$-resorcylic acid and benzoic acid (Fig. 1). The effect greatly decreased at $0.1 \mathrm{mM}$ for all compounds except juglone.
\end{abstract} Lettuce was more susceptible than $E$. utilis. The most effective 8 compounds were then incorporated in soil and bioassayed using germinating lettuce (Fig. 2). Inhibitory activity on lettuce radicle elongation was highest in juglone, followed by coumarin, as in the solution test. The effect on 14 plant species of soil-incorporated coumarin and juglone was also determined. Although juglone fatally inhibited radicle elongation of all test species at $2.0 \mu \mathrm{mol} / \mathrm{g}$ soil, phytotoxic activity of coumarin at $2.0 \mu \mathrm{mol} / \mathrm{g}$ soil differed greatly among the species, and the activity of both compounds at 0.2 and $0.4 \mu \mathrm{mol} / \mathrm{g}$ soil also differed among them (Fig. 3). In this case the

* Part of this paper was presented at the 33rd Annual Meeting of the Weed Science Society of Japan and at the 15th Asian Pacific Weed Science Society Conference, Tsukuba

** Laboratory of Weed Science, Graduate School of Agriculture, Kyoto University, Kyoto 606-8502, Japan

(Accepted January 12, 1998) sensitivity of test plants did not relate to the family of species, but seemed to have some relationships with their seed size. The larger seed species tended to be less sensitive to both compounds, while sensitivity of the small seed species varied over a wide range (Fig. 4).

Key words: phenolic compounds, coumarin, juglone, soil incorporation, sensitivity of test plants

\section{Introduction}

Phenolic compounds are secondary compounds synthesized by vascular plants, composing lignins in cell walls and occurring as either a free or conjugated style of glycosides and esters in the various plant tissues $^{23)}$. Numerous naturally occurring phenolic compounds, mostly phenolic acids, have been studied extensively from the allelopathic point of view ${ }^{23}$. They have been shown to be phytotoxic and are regarded as responsible for allelopathic phenomena in weed-crop interference and population shifts of weeds, due to their activities in bioassay. However, bioassay methods to determine their activity were so diverse in concentration of compounds, ways of application and test species, that growth inhibitory levels reported often differed by 10 times or more for the same compound, e. g. benzoic acid ${ }^{2,14)}$, salicylic acid ${ }^{2,5,14)}, p$-hydroxybenzoic acid ${ }^{5)}, p$ -coumaric acid $^{5)}$ and vanillic acid ${ }^{5}$. Consequently, the results were not always reliable 
enough for the compounds to be categorized as allelopathic agents, although a few strong inhibitors such as juglone have been confirmed as allelochemicals.

Real allelochemicals necessarily have high phytotoxic activity to certain plant populations under certain natural conditions. For conclusive proof of allelopathy, lab bioassays must demonstrate the effect of chemicals on associated plant species ${ }^{17}$. Large numbers of controlled lab bioassay have adopted simple conditions such as aqueous solution and a few test species. But these bioassay methods would lead to overestimation of the activity of compounds, because bioassay in aqueous solution would exclude the effect of adsorption and/or decomposition of compounds in soil and the effect on a few test species might not apply to other species.

Therefore, the objectives of this study were to evaluate: 1) the relative phytotoxic activity of 21 naturally occurring phenolic compounds which had been implicated in allelopathy, and 2) how the activity changes when applied in soil and to various test species.

\section{Materials and Methods}

Aqueous solution test. Commercially available phenolic compounds of analytical-grade (catechol, benzoic acid, salicylic acid, $\beta^{-}$ resorcylic acid, gentisic acid, protocatechuic acid, $\alpha$-resorcylic acid, gallic acid, vanillic acid, syringic acid, $t$-cinnamic acid, $p^{-}$ coumaric acid, caffeic acid, ferulic acid, sinapic acid, $o$-hydroxyphenylacetic acid, 3phenylpropionic acid, coumarin, juglone and chlorogenic acid) were used. Each compound was initially dissolved in dimethylsulfoxide and diluted with distilled water to a final concentration of $1.0 \mathrm{mM}$ or $0.1 \mathrm{mM}$. Germinating seeds of lettuce (Lactuca sativa L., cv. 'Great lakes 366') and Japanese barnyard millet (Echinochloa utilis Ohwi et Yabuno, cv. 'Green millet'), 20 seeds each, were placed in $6 \mathrm{~cm}$ glass petri dishes, and $4 \mathrm{ml}$ of the test solution was added to each dish with 3 replications. The dishes were then placed in an incubator controlled at $25^{\circ} \mathrm{C}$, light $(34 \mu \mathrm{mol} /$ $\mathrm{sec} \cdot \mathrm{m}^{2}$ ). Radicle length of Japanese barnyard millet and lettuce was measured on the 4 th and 6 th days, respectively.

Soil incorporation test. The eight most effective compounds, 3-phenylpropionic acid, $t$-cinnamic acid, $o$-hydroxyphenylacetic acid, salicylic acid, benzoic acid, $\beta$-resorcylic acid, coumarin and juglone, were selected according to the result of the solution test and used in a further bioassay with soil. Plastic cups, $6 \mathrm{~cm}$ in diameter and $3.5 \mathrm{~cm}$ deep, were filled $30 \mathrm{~g}$ in each cup with nonsterilized sandy loam soil filtered with 2.0 $\mathrm{mm}$ mesh (pH: 5.9, clay content: $12 \%$, organic matter content: $2 \%$, CEC: $10.2 \mathrm{me} /$ $100 \mathrm{~g}$ ) collected from the Experimental Farm of Kyoto University. The compounds were added as aqueous solutions and mixed with soil carefully, final concentrations being 0.2 , 0.4 and $2.0 \mu \mathrm{mol} / \mathrm{g}$ soil and soil moisture being at $79.7 \%$ of the field capacity $(\mathrm{pF}=$ 2.0). Five germinating lettuce seeds per cup were planted $5 \mathrm{~mm}$ deep. The cups were covered with polyvinyl film and then incubated under $25{ }^{\circ} \mathrm{C}$, light $\left(12 \mu \mathrm{mol} / \mathrm{sec} \cdot \mathrm{m}^{2}\right)$. For each treatment 4 cups were used. Radicle and hypocotyl length was measured 5 days after planting.

Comparison of test species. The phytotoxic activity of juglone and coumarin, two of the most distinguished inhibitory compounds in the previous tests, was assayed on 12 weed species collected from agricultural land or non-agricultural land in Kyoto prefecture (Poaceae: Sacciolepis indica (L.) Chase; 
Eleusine indica (L.) Gaertn.; Panicum bisulcatum Thunb.; Digitaria ciliaris (Retz.) Koel., Asteraceae: Erigeron sumatrensis Retz.; Artemisia indica Willd., Polygonaceae: Persicaria lapathifolia (L.) S. F. Gray, Lamiaceae: Leonurus japonicus Houtt., Amaranthaceae: Amaranthus patulus Bertoloni, Onagraceae: Oenothera biennis L., Portulaceae: Portulaca oleracea L., and Cyperaceae: Cyperus iria L.), lettuce and Japanese barnyard millet. Seed germination of all the species was over $80 \%$, and only germinating seeds were used. All other procedures were the same as described above.

\section{Results}

Comparison among compounds. Phytotoxic effects varied greatly among the 21 phenolic compounds (Fig. 1). Lettuce was more sensitive than Japanese barnyard millet on the whole. According to the response of both species at $1.0 \mathrm{mM}$, these compounds could be classified into the following three categories in their phytotoxic activity:
Very active: 3 -phenylpropionic acid, $t$-cinnamic acid, $o$-hydroxyphenylacetic acid, coumarin and juglone at $1.0 \mathrm{mM}$ caused almost complete inhibition of radicle elongation of both test plants. Juglone was recognized the most active compound from its activity at $0.1 \mathrm{mM}$, followed by coumarin.

Relatively active: salicylic acid, benzoic acid and $\beta$-resorcylic acid were ranked in this group from the responses of both species at $1.0 \mathrm{mM}$.

Slightly active or non-active: catechol, $p$ hydroxybenzoic acid, $\alpha$-resorcylic acid, gentisic acid, protocatechuic acid, gallic acid, vanillic acid, syringic acid, $p$-coumaric acid, caffeic acid, ferulic acid, sinapic acid, and chlorogenic acid, caused little or no inhibition of radicle elongation in Japanese barnyard millet, although the activity in lettuce varied. Phytotoxic symptoms in the test plants were different between the compounds: $t$-cinnamic acid, $o$-hydroxyphenylacetic acid, 3-phenylpropionic acid and coumarin caused swelling of lettuce radicles; salicylic acid and $\beta$-resor-
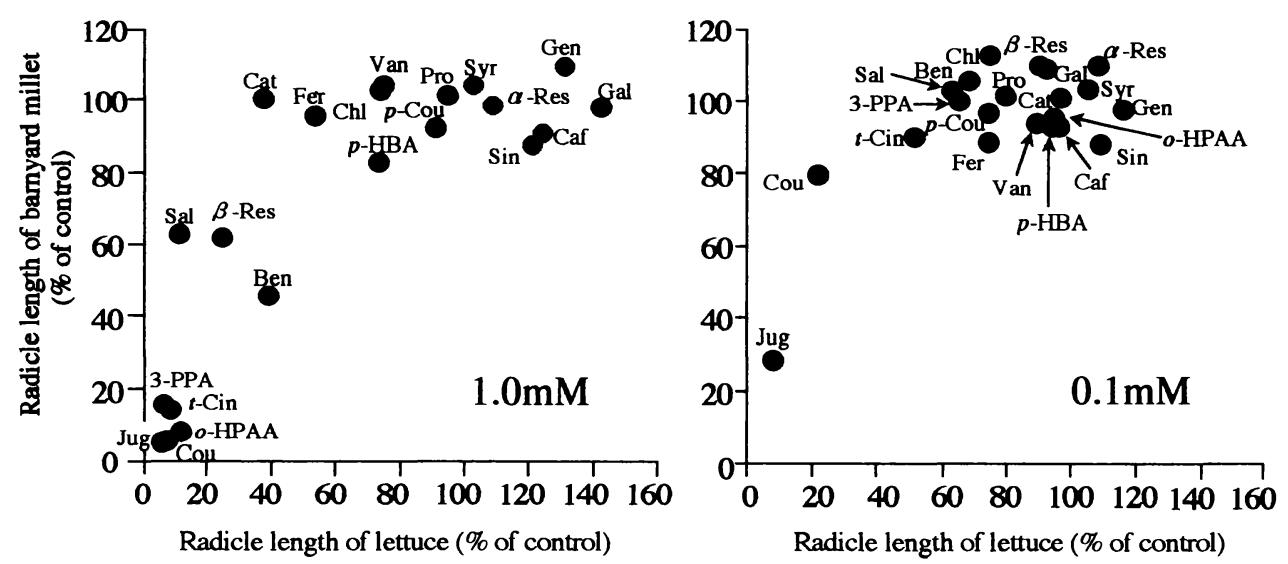

Fig. 1. Effects of aqueous solutions of phenolic compounds on the radicle elongation of Japanese barnyard millet and lettuce. Abbreviations: $o$-HPAA $=o$-hydroxyphenylacetic acid, 3 -PPA $=3$-phenylpropionic acid, $p$ -HBA $=p$-hydroxybenzoic acid, Cat $=$ catechol, Ben $=$ benzoic acid, Sal $=$ salicylic acid, $\beta$-Res $=\beta$-resor cylic acid, Gen $=$ gentisic acid, Pro $=$ protocatechuic acid, $\alpha$-Res $=\alpha$-resorcylic acid, Gal $=$ gallic acid, Van $=$ vanilic acid, Sry $=$ syringic acid, $t$-Cin $=t$-cinnamic acid, $p$-Cou $=p$-coumaric acid, Caf $=$ caffeic acid, $\mathrm{Fer}=$ ferulic acid, $\mathrm{Sin}=$ sinapic acid, $\mathrm{Cou}=$ coumarin, $\mathrm{Jug}=$ juglone and $\mathrm{Chl}=$ chlorogenic acid 
cylic acid caused necrosis at the top and around the base of lettuce radicles, respectively; curving of cotyledons occurred in juglone treated lettuce; lateral expansion of leaf blades occurred in coumarin treated Japanese barnyard millet.
Effects of soil-incorporated application of the 8 compounds most active in the solution test are shown in Fig. 2. Inhibitory activity on lettuce radicle elongation was highest in juglone, followed by coumarin, as in the solution test. Juglone both applied as aqueous solution

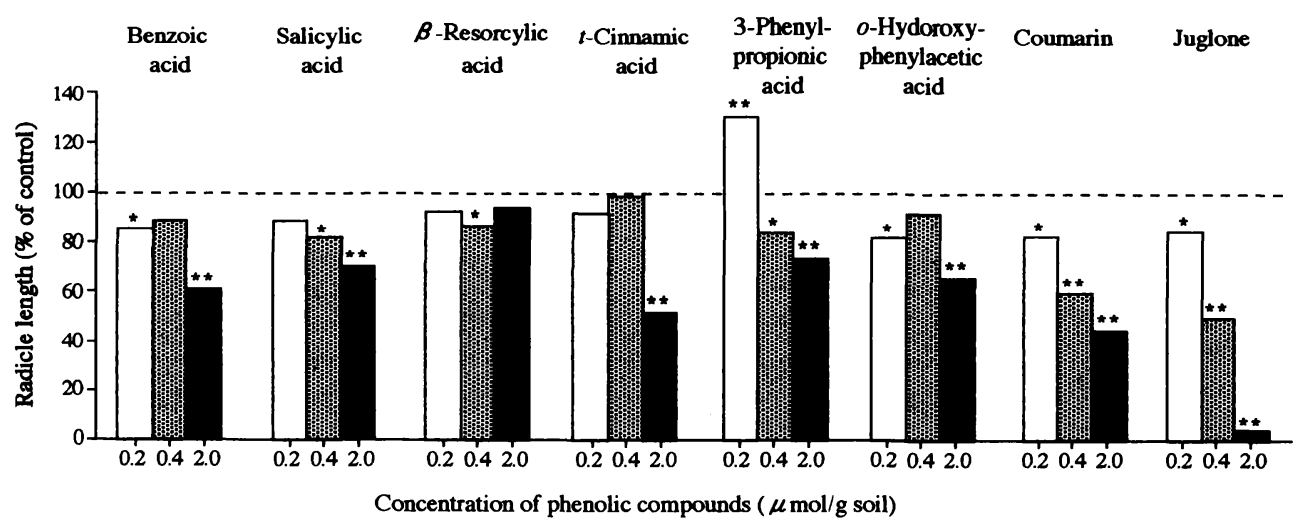

Fig. 2. Effects of soil-incorporated phenolic compounds on radicle elongation of lettuce. *and ${ }^{* *}$ indicate significant difference from control at the $5 \%$ and $1 \%$ levels by $\mathrm{t}$-test, respectively.

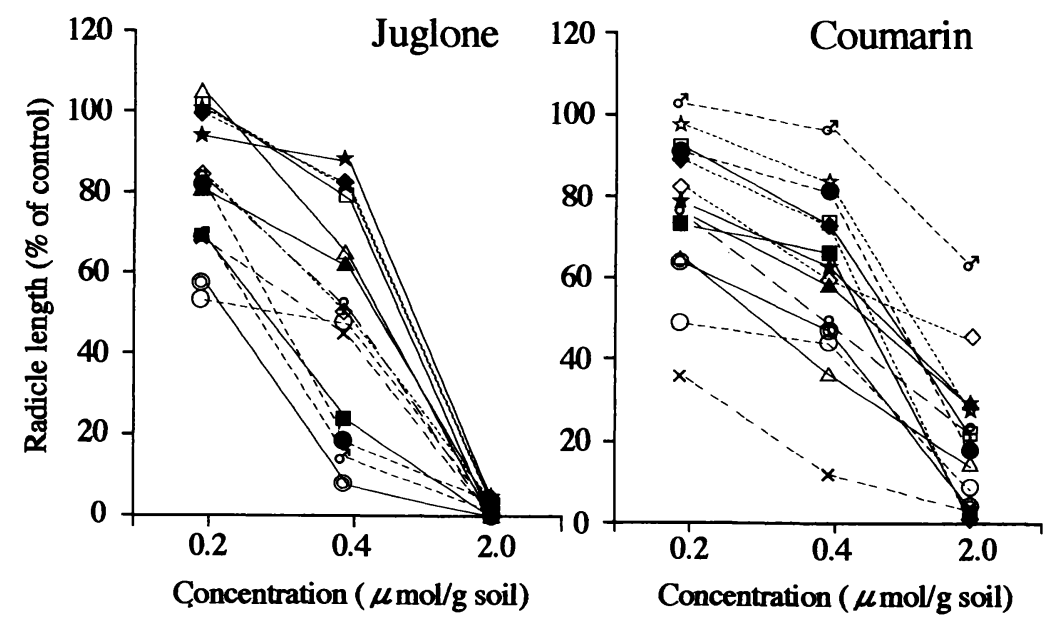

Fig. 3. Effects of soil-incorporated juglone and coumarin on radicle elongation of 14 tested species.

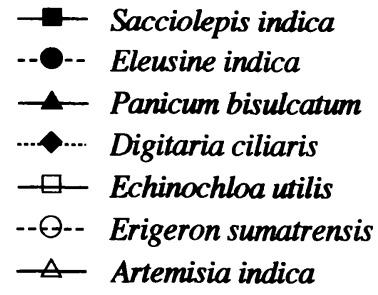

... $\diamond$ Lactuca sativa

* Persicaria lapathifolia

...-s.... Leonurus japonicus

- Amaranthus patulus

--ه-- Oenothera biennis

- ㅇ - Portulaca oleracea

--x- - Cyperus iria 

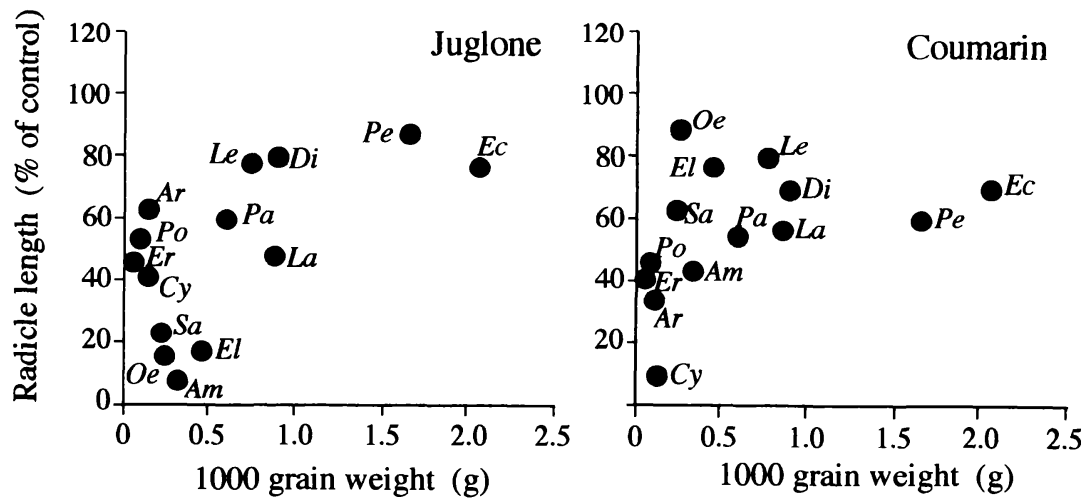

Fig. 4. Relationship between seed size and susceptibility of tested species to juglone and coumarin soil-incorporated at $0.4 \mu \mathrm{mol} / \mathrm{g}$ soil. The letters near each circle are the first two letters of the genus name of the test plants. Test conditions were the same as Fig. 3.

at $1.0 \mathrm{mM}$ (Fig. 1) and soil-incorporated at $2.0 \mu \mathrm{mol} / \mathrm{g}$ soil (Fig. 2) exhibited almost equally strong inhibition, while the inhibitory activity of the other 7 compounds decreased when incorporated in soil. $\beta$-resorcylic acid which showed a very strong effect in the solution test had little effect in the soil test.

\section{Comparison among test plants. Responses} to juglone and coumarin of 14 species, 12 weed species belonging to different genera, lettuce and Japanese barnyard millet, were determined by soil-incorporated treatments (Fig. 3). At $2.0 \mu \mathrm{mol} / \mathrm{g}$ soil, juglone fatally inhibited radicle elongation of all test species, but the activity of coumarin varied among the species. At 0.2 and $0.4 \mu \mathrm{mol} / \mathrm{g}$ soil, sensitivity differed greatly among the species, ranging from no inhibition to almost complete inhibition in the two compounds. The phytotoxic activity of juglone and coumarin was generally reduced at $0.2 \mu \mathrm{mol} / \mathrm{g}$ soil, but these compounds were still inhibitory to most of the species tested.

Sensitivity of the species to juglone and coumarin as evaluated from their responses at $0.4 \mu \mathrm{mol} / \mathrm{g}$ soil is presented in Fig. 4 , in relation to their seed weight. The larger seed species of Japanese barnyard millet, Persicaria lapathifolia, Digitaria ciliaris, Leonurus japonicus, lettuce and Panicum bisulcatum tended to be less sensitive to both compounds, while sensitivity of the small seed species varied widely (Fig. 4). Sensitivity of the small seed species, except for Portulaca oleracea, also differed greatly between the two compounds.

\section{Discussion}

The phytotoxic activity markedly varied among the compounds: juglone and coumarin were the most phytotoxic compounds in the aqueous solution test (Fig. 1). The strong activities of juglone, one of the most phytotoxic allelochemicals produced by black walnuts (Juglans nigra), as well as coumarin were also proved in many other studies $^{1,5,11,23)}$. Among the other compounds, 3 -phenylpropionic, $t$-cinnamic and $o$-hydroxyphenylacetic acid also showed strong activity. Reynolds ${ }^{18)}$ reported that methylation increased activity of aromatic compounds while hydroxylation decreased it, but exceptions were seen with ortho-hydroxylated compounds. Our result supported this because 3-phenylpropionic and $t$-cinnamic acid do 
not have a hydroxyl substituent and $0^{-}$ hydroxyphenylacetic acid has an orthohydroxyl substituent. Other studies comparing several phenolic compounds also showed a similar phytotoxic tendency ${ }^{4,11,14,18,23)}$ to our results.

Furthermore, the result of the soil incorporating test showed a decrease of phytotoxicity of most of the compounds in soil (Fig. 2), although they had similar activity to juglone in the aqueous solution test. When the compounds were added to the soil at concentrations of 0.2 and $0.4 \mu \mathrm{mol} / \mathrm{g}$ soil, most of them except coumarin and juglone did not show strong phytotoxicity. Levels of individual phenolic acids were usually found far below $0.1 \mu \mathrm{mol} / \mathrm{g}$ soil ${ }^{2,3,13,20,21,22)}$, even under a condition such as stubble mulch or just after plant residues were incorporated. Results of the soil incorporating test, together with that of the aqueous solution test (Fig. 1), therefore suggested that most of the phenolic acids have little effect.

All the above findings seem to support the opinion that most of the phenolic acids, by themselves, should not be categorized as allelochemicals. It nevertheless cannot be denied that these compounds could be implicated in allelopathic phenomena in certain situations. Synergistic interaction between some phenolic acids ${ }^{7,12,23)}$ could be suggested, although Duke ${ }^{5}$ pointed out that these may have been the result of improper statistical analysis. Another possible interaction of which Rice $^{19)}$ pointed out the importance is that of the environment: hig temperature increased the effect of ferulic acid on the seedlings of soybean and sorghum ${ }^{6)}$ and allelopathy of Eupatorium odoratum was enhanced under a shaded condition ${ }^{16)}$.

In the case of coumarin and juglone, the most phytotoxic compounds, their phytotoxicity among the 14 test species differed (Fig.
3). This different sensitivity among species did not relate to the botanical family of the test species, but to the seed size (Fig. 4). As shown in Fig. 4, relatively large seed species tended to be tolerant of juglone and coumarin. This tendency was also obvious in the result obtained by Williams and Hoagland ${ }^{23)}$, in which cultivated species (cotton, sorghum, corn and cantaloupe) and relatively large seed weed species (sicklepod and hemp sesbania) were tolerant to both these compounds at a level of which small seed species, velvetleaf, redroot pigweed, prickly sida, were very susceptible. Redroot pigweed (Amaranthus retroflexus) was most susceptible to juglone in their experiment like Amaranthus patulus in this study. Decreased sensitivity of the larger seed species was also found for the herbicides atrazine ${ }^{15)}$, benthiocarb $^{9)}$, alachlor ${ }^{8)}$ and oxadiazone ${ }^{10)}$. In contrast, as indicated in Fig. 4, responses of small seed species all of them weeds to juglone and coumarin varied over a wide range, and different sensitivity of Oenothera biennis, Cyperus iria, Amaranthus patulus and Eleusine indica was exhibited to both compounds. Therefore, it is assumed that different responses of species to the allelochemicals may depend on both seed size and intrinsic sensitivity of the species.

The study also suggested that bioassay of phytotoxic compounds should be done under a certain standard by which the result could be evaluated impartially. Using a wellknown strong inhibitor such as juglone or coumarin for the check is useful device from this point of view. In addition, not one but several test plants should be selected both from crop and weed species covering a wide range of seed size. Adoption of weed species for test plants is particularly important to determine the allelopathic potential of the compounds which are assumed to implicate 
weed population shifts or weed-crop interference.

\section{References}

1) Audus, L. J. and J. H. Quastel 1947. Coumarin as a selective phytocidal agent. Nature 159, 937944.

2) Chou, C. H. and Z. A. Patrick 1976. Identification and phytotoxic activity of compounds produced during decomposition of corn and rye residues in soil. J. Chem. Ecol. 2, 369-387.

3 ) Chou, C. H. and C. C. Young 1975. Phytotoxic substances in twelve subtropical grasses. J. Chem. Ecol. 1 (2), 369-387.

4 ) Demos, I. K., M. Woolwine, R. H. Wilson and C. McMillan 1975. The effects of ten phenolic compounds on hypocotyl growth and mitochondrial metabolism of mung bean. Am. J. Bot. 62, 97-102.

5 ) Duke, S. O. 1986. Naturally occurring chemical compounds as herbicides. Rev. Weed Sci. 2, pp. 15-44.

6 ) Einhellig, F. A. and P. C. Eckrich 1984. Interaction of temperature and ferulic acid stress on grain sorghum and soybeans. J. Chem. Ecol. 10, 161-170.

7) Einhellig, F. A. and J. A. P. Rasmussen 1978. Synergistic inhibitory effects of vanillic and $p^{-}$ hydroxybenzoic acids in radish and grain sorghum. J. Chem. Ecol. 4, 425-436.

8) Harvey, R. G. 1974. Susceptibility of seven annual grasses to herbicides. Weed Res., 14, 5155.

9) Ichizen N. 1979. Study on the difference in susceptibility and growth response of rice and barnyardgrass against Benthiocarb. Ph D dissertation, Kyoto University, Kyoto, Japan. (in Japanese)

10) Kawamura, Y. 1975. Studies on a new herbicide, oxadiazone 3. Weed Res., Japan 20, 55-60. (In Japanese with English summary)

11) Kitou, M. 1997. Effects of 16 kinds of phenolic compounds on the germination and root elongation of several plants. Jour. Weed Sci. Tech. 42 (Suppl.) 114-115. (In Japanese)

12) Li H. H., M. Inoue, H. Nishimura, J. Mizutani, and $\mathrm{E}$. Tsuzuki 1993. Interactions of trans-cin- namic acid, its related phenolic allelochemicals, and abscisic acid in seedling growth and seed germination of lettuce. J. Chem. Ecol. 19 (8), 1775-1787.

13) Li H. H., L. Lajide, H. Nishimura, K. Hasegawa, and J. Mizutani 1993. Allelochemicals in the soil beneath Quercus mongolica Fisch var. grosseser. rata Rehd. Wils. Weed Research, Japan 38 (4), 282-293.

14) Lynch, J. M. 1980. Effects of organic acids of the germination of seeds and growth of seedlings. Plant, Cell and Environment. 3, 255-259.

15) Mennega, R. and P. C. Nel. 1991. Tolerance of dry bean cultivars (Phaseolus spp.) to atrazine. Appl. Plant Sci. 4, 78-81.

16) Nakamura, N. and M. Nemoto. 1994. Combined effects of allelopathy and shading in Eupator. ium odoratum on the growth of seedlings of several weed species. Weed Research, Japan 39, 27-33. (In Japanese with English summary)

17) Putnam, A. R. and C. S. Tang. 1986. Allelopath$\mathrm{y}$ : state of science. In "The Science of Allelopathy" ed. by A. R. Putnam and C. S. Tang. Jone Wiley, New York. pp. 1-19.

18) Reynolds, T. 1978. Comparative effects of aromatic compounds of inhibition of lettuce fruit germination. Ann. Bot. 42, 419-427.

19) Rice, E. L. 1984. Allelopathy, 2nd edition, Acad. Press, Orlando, 422 pp.

20) Shindo, H., S. Ohta and S. Kuwatsuka 1978. Behavior of phenolic substances in the decaying process of plants IX. Distribution of phenolic acids in soils of paddy fields and forests. Soil Sci. Plant Nutr. 22 (1), 23-33.

21) Wang, T. S. C., T. K. Yang and T. T. Chuang 1967. Soil phenolic acids as plant growth inhibitors. Soil Sci. 103, 239-246.

22) Whitehead, D. C. 1964. Identification of $p^{-}$ hydroxybenzoic, vanillic, $p$-coumaric and ferulic acids in soils. Nature. 202, 417-418.

23) Williams, R. D. and R. E. Hoagland 1982. The effects of naturally occurring phenolic compounds on seed germination. Weed Sci. 30, 206212. 
自然界にみられるフェノール化合物の 生育抑制作用の評価

小林由佳* 伊藤操子*

\section{摘 要}

アレロケミカルとして過去に報告されたことのあ る21種類のフェノール化合物の阻害活性を水溶液試 験と土壌混和試験によって相対的に評価した。水溶 液試験では, juglone, coumarin, $t$-cinnamic acid, $o$-hydroxyphenylacetic acidおよび3-phenylproponic acid は1.0mM においてレタスと栽培ヒエ の幼根の伸長を顕著に阻害し, salicylic acid, $\beta$ resorcylic acid および benzoic acid の阻害活性がそ れに準じた。0.1mM では juglone を除く全ての化合 物の阻害活性が滅少した。また, レタスは栽培ヒエ より強く阻害された (Fig. 1)。次に水溶液の阻害活

* 京都大学大学院農学研究科雑草学研究室
性が最も高かった 8 種類のフェノール化合物を土壌 に混和して,レタス幼根の伸長に対する影響を調査 した。juglone は最も高い阻害活性を示し, coumarin がそれに準じた (Fig. 2)。また，14種の供試植物に 対して土壤に混和した juglone と coumarin が与え る影響を調査した。juglone は $2.0 \mu \mathrm{mol} / \mathrm{g}$ 土壤にお いて全ての供試植物の幼根伸長を強く阻害したが, 同じ濃度における coumarin の阻害活性は供試植物

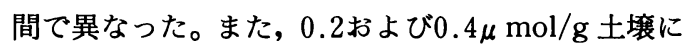
おいては両化合物の阻害活性が供試植物間で異なっ た (Fig. 3)。この場合, 供試植物の感受性は供試植 物の科とは関係なかったが, 種子の大きさとは関係 があるようであった。両化合物の阻害活性は大きな 種子の供試植物では小さいが, 小さな種子の供試植 物については種によってその感受性が大きく異なっ た (Fig. 4)。

キーワード：フェノール化合物, coumarin, juglone, 土壌混和, 供試植物の感受性 